\title{
CONCLUSION
}

Monitoring and assessing the implementation of the treaties and evaluating their effectiveness is a complex process. The effectiveness of treaties and the monitoring bodies depends on a genuine willingness of states parties themselves to respect and ensure the rights stipulated in the treaties, as well as the involvement of active NGOs, UN agencies, and individuals.

Cynical observers may argue that states parties may simply ignore recommendations they dislike due to the absence of a strong enforcement mechanism, and even the most passionate supporters of the treaty system are aware of its shortcomings. However, experience demonstrates that the work of the treaty bodies has become an important framework for change, with much depending on those involved in the process to work for real changes in practice on the ground.

Moreover, the system is exploring measures to encourage and enable compliance and provide an effective mechanism for public pressure to hold violators accountable. Greater efforts are needed to ensure that the reporting system can reach its fullest potential, particularly in terms of adequate data collection and analysis and formulation of sound implementation strategies. Little will be settled without carefully designed empirical studies that assess the impact of the treaties and their monitoring procedures and give real guidance on the causal factors that facilitate or obstruct compliance.

In the meantime, current reform initiatives must be supported and the value of the core treaties reaffirmed. Those treaties set the benchmarks against which the behavior of states parties must be measured. Efforts should be concentrated on ensuring that the rights enshrined in those treaties are afforded to all those who need them most, in every corner of the globe.

\section{THE NEW EMPIRICISM IN HUMAN RIGHTS: INSIGHTS AND IMPLICATIONS}

\section{by Oona A. Hathaway*}

More than fifty years ago, the nations of the world came together to make a revolutionary pledge: Together, they would work to promote "universal respect for and observance of human rights and fundamental freedoms."1

Although significant progress has been made toward this goal in the half-century since, the world remains rife with human rights abuses. In Haiti, the turmoil unleashed in the wake of Aristide's removal from power has opened the door to growing violence. In Nigeria, the weeks leading up to local elections saw politically motivated killings and the use of violence to secure votes. Ethnic violence continues to seethe in the former Yugoslavia, with recent news of attacks on Serbs by ethnic Albanians.

The continuing - and in some parts of the world worsening - reality of human rights violations raises a difficult question for advocates and students of international law: Can international human rights law be used to help bring an end to such atrocities?

To answer this question, we must first know something about the effect of current international laws on states' human rights practices. How do the existing human rights treaties shape state behavior? Are some more effective than others? If so, why?

\section{THE STUDY OF HuMAN Rights LAW}

Until recently, there were few systematic efforts to explore these issues. Advocates of international law tended to operate on the assumption that the laws were effective "most of the time." Skeptics derided the role that international law could play in shaping state behavior,

\footnotetext{
- Associate Professor of Law, Yale Law School.

${ }^{1}$ Universal Declaration of Human Rights, GA Res. 217A (III), UN Doc. A/810 (1948).
} 
arguing that because it carried few explicit sanctions, international law could not be effective. Neither side spent much time considering what worked and what did not, much less why.

In recent years, this has begun to change. A burgeoning new literature on compliance with international human rights law has contributed greatly to our understanding of the impact of human rights law on the human rights practices of states.

Two types of research have predominated. The first-the staple of empirical research in the human rights field - has been qualitative case studies that examine particular treaties or countries in great depth and give detailed evidence of how one or several countries have reacted to international law. For example, Laurence Helfer offers a revealing study of what he terms the overlegalization of international human rights law in three Commonwealth Caribbean countries. ${ }^{2}$ Ellen Lutz and Kathryn Sikkink examine the impact of human rights prohibitions on torture, disappearances, and democratic governance in several Latin American countries. ${ }^{3}$ These works and others of a similar character provide deep insights into how law can influence state action.

The obvious drawback of this work, however, is that it is not well suited to the task of isolating the role that law plays in changing state behavior. When a state begins to torture less frequently, for instance, it is difficult to determine with a historical case study whether the change is due to ratification of an international legal convention, the cessation of a civil war, improved economic conditions, some combination of these changes, or something else entirely.

In response to this problem, a second set of empirical scholarship uses large-N quantitative methods to explore the effect of international law on human rights practices. This work assesses the human rights practices of large numbers of countries in an effort to analyze the impact of law on state practice. ${ }^{4}$ My own work, for example, has sought to examine the effect of several universal and regional human rights agreements on state use of torture, fair trial practices, civil liberties, genocide, and women's political representation. ${ }^{5}$

This work, of course, has its own limitations. Most notably, the results of quantitative empirical work are only as good as the data on which they rest, and the data are sparse and sometimes - though, I would argue, far from universally - of questionable value. Hence, conclusions from this work must be drawn with caution. ${ }^{6}$

\section{KEY FINDINGS OF EXISTING STUdIES}

Together, these two types of empirical work have greatly enriched our understanding of the relationship between international human rights law and the human rights practices of states. Quantitative studies have identified trends and relationships across large numbers of countries and significant periods of time. Qualitative case studies have examined trends on the ground, tested the plausibility of causal claims, and provided the context necessary for a deep understanding of causal relationships.

\footnotetext{
${ }^{2}$ Laurence R. Helfer, Overlegalizing Human Rights: International Relations Theory and the Commonwealth Caribbean Backlash Against Human Rights Regimes, 102 COLUM. L. REV. 1832 (2002).

${ }^{3}$ Ellen L. Lutz \& Kathryn Sikkink, International Human Rights Law and Practice in Latin America, 54 INT'LORG. 633 (2000).

${ }^{4}$ Oona A. Hathaway, Do Human Rights Treaties Make a Difference?, 111 YALE L.J. 1935, 1935-2042 (2002); Oona A. Hathaway, The Cost of Commitment, 55 STAN. L. REV. 1821 (2003); Oona A. Hathaway, Why Do Nations Join Human Rights Treaties? (unpublished manuscript, on file with author); Linda Camp Keith, The United Nations International Covenant on Civil and Political Rights: Does It Make a Difference in Human Rights Behavior?, 36 J. PEACE RES. 95 (1999); and Beth Simmons, Why Commit? (unpublished manuscript, on file with author).

${ }^{5}$ Hathaway, Do Human Rights Treaties Make a Difference?, supra note 4.

${ }^{6}$ For a debate over the pros and cons of quantitative empirical research, see Oona A. Hathaway, Testing Conventional Wisdom, 13 EUR. J. INT'L L. 185 (2003); Ryan Goodman \& Derek Jinks, Measuring the Effects of Human Rights Treaties, 13 EUR. J. INT'L L. 171 (2003).
} 
Several valuable insights have emerged from this growing body of empirical human rights research, three of which deserve special attention. ${ }^{7}$

\section{Domestic Enforcement of International Law Is Essential to Compliance}

Strong domestic institutions are essential to the international as well as the domestic rule of law. Where international bodies are less active in enforcement of treaty commitments-as in the area of human rights - it falls to domestic institutions to fill the gap. In some states, this reliance on domestic institutions is effective, in others, less so. In democratic nations, where domestic enforcement tends to be relatively strong (in part because the judiciary, media, and political parties are free to operate independent of the executive), states are more likely to abide by international law whether or not it is externally enforced. In less democratic nations, where domestic enforcement tends to be less effective, states are less likely to abide by international law that is not enforced by transnational bodies.

Indeed, the most robust finding in the empirical literature to date is that democratic nations behave differently with regard to international law than do nondemocratic nations. Andrew Moravcsik in examining the European Convention on Human Rights argues that international treaties offer states a means of consolidating democratic achievements, "thereby enhancing their credibility and stability vis-à-vis nondemocratic political threats." several multilateral and regional human rights treaties explores the role of democracy beyond the European context. In doing so, it reinforces Moravscik's claim that democracy matters, while challenging the specific spin he puts on the argument.

I find that democracies are on the whole more likely to join international human rights treaties than nondemocracies, but they are less likely to join human rights treaties if they have worse human rights practices than if they have better practices. By contrast, nondemocracies are more likely to join if they have worse practices than if they have better practices. Moreover, only the most democratic states appear to improve their practices after ratifying human rights treaties. $^{9}$

\section{There Appears to be a Tradeoff Between Participation in and the Effectiveness of Human Rights Treaties}

Although enforcement of international law by international actors is not essential to effective international law, it is far from irrelevant. Where international legal rules are accompanied by sanctions for their violation, there are several predictable results. Perhaps most obvious, where penalties for noncompliance with an international legal rule are significant, states not already in compliance are less likely to commit to a treaty. Hence, unless the sanctions are offset by incentives favoring commitment (such as strong reciprocal benefits to membership), treaties that contain such sanctions will gain fewer adherents. Thus, there is a tradeoff between enforcement and commitment: Where enforcement is stronger, all else being equal fewer countries should be expected to commit. However, those fewer adherents will be more likely to comply with the treaty than they would be if the treaty were less strongly enforced.

The Convention Against Torture is a compelling example of this dynamic. My research found that countries with the worst torture ratings and countries with the best both ratify the Convention at roughly the same rate. I find similar results for a wide array of human rights treaties.

\footnotetext{
${ }^{7}$ The following is adapted from a lengthier discussion in Oona A. Hathaway, Between Power and Principle: $A$ Political Theory of International Law, 71 U. CHI. L. REV. (forthcoming May 2005).

${ }^{8}$ Andrew Moravcsik, The Origins of Human Rights Regimes: Democratic Delegation in Postwar Europe, 54 INT'L ORG. 217, 220 (2000).

${ }^{9}$ These findings are discussed in more depth in Hathaway, Do Human Rights Treaties Make a Difference?, supra note 4; Hathaway, The Cost of Commitment, supra note 4; and Hathaway, Why Do Nations Join Human Rights Treaties?, supra note 4.
} 
While the states that join human rights treaties usually have better practices than those that do not, the difference between the two groups of nations is much smaller than many would expect. Moreover, states with poor human rights practices regularly join human rights treaties, sometimes at a rate similar to that of countries with the very best human rights practices. For example, roughly half the countries with the very worst genocide ratings have ratified the Genocide Convention - about the same portion of those with the very best ratings.

In fact, holding political and economic factors constant, states with good human rights records are no more likely to commit to human rights treaties than those with poorer records. Among nondemocratic nations, the pattern is even more striking: Nondemocratic nations with worse reported human rights practices appear more likely to have ratified human rights treaties than those with better reported practices. ${ }^{10}$

\section{Nonlegal Incentives Have Power}

Nonlegal incentives play an important role in state decisions to participate in and comply with international law. Several implications arise from this finding, one of which I will discuss here: Membership in certain treaties can boost a state's reputation, often regardless of whether the member state actually abides by the treaty. This is possible because the international community does little to police many treaties, which means that member states that do not police themselves may have little risk of exposure if they fail to abide by treaty requirements. As a consequence, states that violate treaties and have weak domestic rule-of-law institutions have every reason to join treaties that confer reputational benefits, such as human rights treaties. It can be expected that states that join treaties primarily to obtain such benefits will not always comply with them, and sometimes have even worse practices subsequent to commitment.

Several of the empirical studies of human rights treaties support these claims. States regularly join treaties with which they are not in compliance. Indeed, the states with the best human rights practices (and hence the best reputations) are often more reluctant to join human rights treaties than those with worse practices (and hence worse reputations). This suggests that states with better practices have little to gain and something to lose by joining the treaties, whereas the opposite is true of states with poor practices. This supposition finds support in the additional finding that states that join human rights treaties regularly fail to improve their practices after doing so, regardless of whether their practices are consistent with the treaties or not. ${ }^{11}$

\section{LESSONS FOR ACTIVISTS, ACADEMICS, AND POLICYMAKERS}

Though empirical work in human rights is still in its infancy, studies to date have helped us to think about human rights law in new ways, and they have offered important clues about how law can shape state behavior. Their findings not only form a foundation for future empirical research; they also offer guidance to policymakers and activists interested in using international law to protect human rights.

Here, I take the opportunity to outline four important goals that draw from the early forays into empirical human rights research.

\section{The Vital (and Improvable) Role of NGOs}

If there is one conclusion that stands out in the research to date, it is that better information about countries' human rights practices is an important first step toward improving those

\footnotetext{
${ }^{10}$ These findings are drawn from Hathaway, The Cost of Commitment, supra note 4; Hathaway, Why Do Nations Commit to Human Rights Treaties?, supra note 4; Hathaway, Why Do Nations Join Human Rights Treaties?, supra note 4.

${ }^{11}$ See Keith, supra note 4 (finding that becoming a party to the International Covenant on Civil and Political Rights does not appear to make a difference in human rights behavior); Hathaway, Do Human Rights Treaties Make a Difference?, supra note 4; and Hathaway, Why Do Nations Join Human Rights Treaties?, supra note 4.
} 
practices. To date, the bulk of the information on human rights practices has been produced by nongovernmental organizations (NGOs). Yet as essential as this information has proven, it has not always been gathered as carefully and systematically as is necessary to make it reliable for tracing causal connections between international law on human rights and the human rights practices of various countries. ${ }^{12}$ A redoubling of these information-gathering efforts and attention to the critiques of existing studies could provide a more solid foundation for efforts to evaluate the successes and failings of existing laws.

\section{Better Connection of Theory and Practice}

The empirical research in human rights has provided a useful starting point for understanding the relationship between international human rights law and countries' human rights practices, but much more research and theorizing remains to be done, and it must be linked to concrete policy recommendations. Academics should continue to contribute to the debate over the effectiveness of human rights treaties by conducting further large-scale quantitative studies as well as additional qualitative case studies.

We can also play an important role in assembling and analyzing the data generated by state actors and NGOs, formulating theories to help organize and explain the information that is generated daily, and helping to guide the information-gathering efforts of other actors. In doing so, we can strive to provide guidance to national and international policymakers on how best to use this information to create a more effective international human rights regime.

\section{Improving the Domestic Rule of Law}

A central conclusion of existing empirical studies of human rights practices is that domestic enforcement of international human rights commitments is crucial to their success. Improving enforcement of and compliance with international human rights agreements is not something that happens only at the international level. As important, if not more important, is enforcement at the domestic level.

Domestic enforcement of international law in turn requires robust domestic rule-of-law institutions and individuals willing to use them to press governments to honor their international legal commitments. National policymakers and practitioners can play a central role in this process. In nations with weak or nascent rule of law institutions, national policymakers can ensure better international legal compliance by working to strengthen local rule of law. Where rule of law institutions are strong, policymakers and practitioners can ensure better compliance with international human rights law by working to maintain those institutions and using them where necessary to press governments to live up to their international commitments.

\section{Understanding Treaty Tradeoffs}

If, as the research indicates, there is a tradeoff between participation in and effectiveness of human rights treaties, international policymakers must look for ways to mediate this tradeoff. Treaties might be structured to offer states assistance to offset some of the costs of compliance. In addition, the fact that there are nonlegal incentives for treaty commitment and compliance

\footnotetext{
${ }^{12}$ For example, Amnesty International and Human Rights Watch both produce excellent reports on countries' human rights practices. Yet these reports are relatively short and do not cover every country every year, making them a poor source for social scientific inquiry. The Freedom House produces one of the very few quantitative human rights indexes, but it has been criticized for lack of replicability and reliability. See FREEDOM HOUSE, FREEDOM IN THE WORLD: THE ANNUAL SURVEY OF POLITICAL RIGHTS AND CIVIL LiBERTIES 1999-2000 (Adrian Karatnycky ed., 2000); Christopher Mitchell et al., State Terrorism: Issues of Concept and Measurement, in GOVERNMENT VIOLENCE \& REPRESSION 1, 20 (Michael Stohl \& George A. Lopez, eds., 1986) (critiquing the Freedom House reports). The U.S. Government also does a set of human rights reports but they have been charged with political bias. E.g., David Carleton \& Michael Stohl, The Role of Human Rights in U.S. Foreign Assistance Policy: A Critique and Reappraisal, 31 AM. J. POL. SCI. 1002, 1007 (1987) (citing and briefly discussing reports of Americas Watch, Helsinki Watch, and the Lawyers Committee for International Human Rights and critiquing the State Department reports for political bias).
} 
suggests that international policymakers could also use these incentives to encourage compliance with international law-by, for instance, placing greater emphasis on monitoring states' compliance with their international human rights treaty commitments. Doing so would make it more costly for states to commit to treaties and then fail to comply with them, and it would more effectively reward states that join treaties and do comply with them, thus lessening the participation-effectiveness tradeoff.

\section{THE RoAD AHEAD}

We have learned a great deal in recent years about how states respond to international human rights law. In the process, we have come to appreciate anew both the power and the weaknesses of the international legal system. International law sets a standard against which state actions are judged - by those both inside and outside the state. It mobilizes the attention of the world to abuse of the world's most vulnerable.

Yet violations of international legal protections remain rife, and current treaties often do little to change what states do. By working to better understand empirically when and why states abide by their international human rights commitments, we can make it possible for international law to more fully realize its great promise. 